\title{
SAJAK-SAJAK IRIANTO IBRAHIM DALAM SITUS KESEDIHAN ANALISIS: SEMIOTIK RIFFATERRE
}

\author{
Kahar Muzakar', Sumiman Udu², La Ode Sahidin ${ }^{3}$ \\ ${ }_{1,2,3}$ Universitas Halu Oleo
}

\begin{abstract}
Email: kaharmuzakar123@gmail.com ${ }^{1}$, sumimanudu75@gmail.com $^{2}$, sahidinlaode@ymail.com ${ }^{3}$
\end{abstract}

\begin{abstract}
Abstrak: Penelitian bertujuan menemukan makna, hubungan, sejarah dan latar belakang terciptanya sajak-sajak Irianto Ibrahim. Metode penelitian ini adalah deskriptif kualitatif. Sajak-sajak Irianto Ibrahim dalam Situs Kesedihan yaitu Sajak Pada Suatu Hari, Sajak Percakapan Selepas Hujan, dan Sajak Yang Berakhir dengan Pertanyaan. Sajak-sajak yang ditulis pada Januari tahun 2019 ini terbagi dalam tiga judul. Namun dilihat dari alur waktu, ketiganya saling terhubung serta melengkapi. Terdapat rentetan cerita yang coba dilanjutkan kembali pada sajak-sajak selanjutnya, mengandung bahasa kiasan dan tanda-tanda menggunakan konotasi dari alam yang menarik untuk ditinjau maknanya. Aspek tersebut dianaliasis dari data berupa buku antologi puisi Situs Kesedihan rangkaian Toni Lesmana menggunakan pendekatan semiotik Riffaterre. Tujuannya untuk mengungkap makna sajak-sajak Irianto Ibrahin dalam Situs Kesedihan. Hasil analisis menunjukan bahwa dalam sajak Pada Suatu Hari, sajak Percakapan Selepas Hujan, dan sajak Yang Berakhir dengan Pertanyaan karya Irianto Ibrahim memiliki makna yang kompleks dan saling berhubungan satu sama lain. Hal tersebut dapat dilihat pada rangkain pencarian makna yang dilakukan menggunakan semiotik Riffaterre.
\end{abstract}

Kata Kunci: Makna Sajak; Semiotik Riffaterre; Situs Kesedihan

\section{Pendahuluan}

Puisi menurut Riffaterre (1978:1) merupakan aktivitas bahasa yang berbeda dengan pemakaian bahasa pada umumnya. Riffaterre (1978: 1) mengatakan, bahwa yang menjadi faktor pembeda antara puisi dan bukan puisi adalah cara sebuah teks puisi membawa maknanya. Dari pengertian tersebut Riffaterre lebih lanjut memberikan sebuah pengertian yang lebih sederhana mengenai struktur makna sebuah puisi. Bagi Riffaterre, fenomena sastra merupakan dialektika antara teks dan pembaca. Konsep ini memberikan ruang gerak yang lebih leluasa bagi para pembaca. Artinya, pembaca memiliki kebebasan memaknai dan menafsirkan puisi tanpa harus merasa terikat oleh maksud pengarangnya. Menurut Siswanto
(2013: 97) puisi merupakan karya yang dimaksudkan oleh pengarang sebagai puisi dan diterima dengan sama oleh pembaca.

Penelitian terhadap buku antologi puisi memiliki daya tarik untuk dilakukan pengkajian. Sebab, puisi-puisi antologi terlebih dahulu diseleksi oleh tim kurator dengan jangka waktu tertentu hingga dipilih dan diterbitkan dalam bentuk kumpulan puisi-puisi. Seperti buku antologi, Situs Kesedihan rangkaian Toni Lesmana, dkk.

Tie Setiadi editor buku antologi puisi Situs Kesedihan mengutarakan penulisan puisi-puisi terpilih dalam Situs Kesedihan terlepas dari masalah klise, banjir emosi, hiperbola, jebakan abstraksi, hasrat menggurui, bermain kata yang 
mengakibatkan kata-kata kehilangan bobot, kejernihan, dan kekuatannya. Irianto Ibrahim berhasil mencatatkan namanya masuk dalam jejeran pengarang yang karyanya dimuat dalam buku Situs Kesedihan tersebut. Karya Irianto Ibrahim yang berhasil lolos dari seleksi tersebut adalah Sajak Pada Suatu Hari, sajak Percakapan Selepas Hujan, dan sajak Yang Berakhir dengan Pertanyaan yang ditulis pada Januari 2019 di Kendari. Menurut Tie Setiadi, Irianto Ibrahim menggoreskan sajak-sajak secara tenang, dalam, mengendap. Ada kesahajaan dalam cara ucap dan diksinya, ada kesabaran dalam mengolah perasaanperasaan kecil (Lesmana, 2019:7). Alhasil sajak-sajaknya mengunggah dan menarik untuk diteliti lebih dalam untuk diketahui makna, maksud yang ditulisnya sebagaimana pula yang dikatakan Riffaterre (1978: 1) bahwa yang menjadi faktor pembeda antara puisi dan bukan puisi adalah cara sebuah teks puisi membawa maknanya, sekaligus hal tersebut menjadi alasan mengapa memilih karya Irianto Ibrahim dibanding sepuluh penyair lainnya yang karyanya dimuat dalam buku antologi Situs Kesedihan, ada keterkaitan antara sajak-sajak Irianto Ibrahim dengan definisi puisi yang dimaksud Riffaterre.

Berdasarkan uraian pada latar belakang, rumusan masalah dalam penelitian ini adalah analisis makna Sajak Pada Suatu Hari, sajak Percakapan Selepas Hujan, dan sajak Yang Berakhir dengan Pertanyaan karya Irianto Ibrahim berdasarkan teori semiotik Riffaterre?

\section{Metode Penelitian}

Metode yang digunakan dalam penelitian ini adalah metode deskriptif kualitatif, Moleong menyebutkan tujuan penelitian kualitatif membangun persepsi alamiah sebuah objek, dengan mendekatkan diri pada objek secara utuh (Jabrohim, 2017: 43). Data penelitian ini bersumber dari buku Situs Kesedihan kumpulan puisi-puisi terbaik Basabasi.co 2019 halaman 58-61, rangkaian Toni Lesmana, dkk, yang diterbitkan oleh Basabasi, cetakan pertama pada April 2019.

Langkah-langkah pengumpulan data dalam penelitian meliputi hal-hal sebagai berikut:

(1) Pencarian makna heuristik dan pencarian makna hermeneutik;

(2) Pencarian ketidaklangsungan ekspresi;

(3) Pencarian matriks, model, dan varian;

(4) Pencarian hipogram potensial dan hipogram aktual.

Riffaterre merekomendasikan metode pembacaan puisi melalui dua tahap pembacaan, yaitu heuristik dan hermeneutik. Pradopo (2011: 227) menjelaskan sajak dibaca secara heuristik yaitu dibaca berdasarkan tata bahasa normatif, morfologi, semantik, dan sintaksis. Faruk (2012:144-146) menjabarkan bahwa pembacaan heuristik dilakukan dengan menggunakan kode bahasa yang bersifat referensial.

Pembacaan itu didasarkan pada sistem dan konvensi bahasa. Karena kenyataan itu bersifat kompleks, pembacaan yang demikian membawa peneliti pada serangkaian makna referensial yang heterogen, tidak bersesuaian satu sama lain, serangkaian ungramatikalitas. Untuk mengatasi hambatan tersebut, peneliti mengambil cara pembacaan yang kedua, yaitu pembacaan hermeneutik.

Pembacaan hermeneutik adalah pembacaan yang bermuara pada ditemukannya satuan makna puisi secara utuh dan terpadu untuk itu dalam memaknai puisi melalui pembacaan hermeneutik dilakukan bersamaan dengan pencarian ketidaklangsungan ekpresi dan pencarian hipogram potensial sebab ketidaklangsungan ekspresi dan hipogram potensial tidak tereksplisitkan dalam teks, 
tetapi harus diabstraksikan dari teks. Pada tahap ini, pembaca dapat memaparkan karya sastra berdasarkan interpretasi pembacaan yang pertama. Dari hasil pembacaan yang pertama, pembaca bergerak lebih jauh untuk memperoleh kesatuan makna (Ratih, 2016: 6).

Selanjutnya mencari matriks, model dan varian dalam sajak berdasarkan hasil analisis heuristik dan hermeneutik secara tekstual dan kontekstual serta hipogram potensial yang telah diuraikan. Matriks merupakan konsep abstrak berupa kata, frase, klausa atau kalimat sederhana yang tidak pernah teraktualisasi dan tidak muncul dalam teks. Model adalah aktulisasi pertama dari matriks, bersifat puitis, yang dapat berupa atau teraktualisasi dengan kalimat-kalimat tertentu. Varian adalah teks secara keseluruhan yang terdiri dari kalimatkalimat model yang telah teraktualisasi. Matriks, model, dan teks adalah varianvarian dari struktur yang sama (Latifi, 2010: 33). Langkah terakhir, pencarian hipogram aktual. Riffaterre memahami puisi sebagai sebuah donat (Faruk, 1996: 25). Apa yang hadir secara tekstual adalah daging donat itu, sedangkan yang tidak hadir adalah ruang kosong berbentuk bundar yang ada di tengahnya dan sekaligus yang menopang dan membentuk daging donat menjadi donat. Ruang kosong yang tidak ada secara tekstual tetapi yang menentukan terbentuknya puisi sebagai puisi itu disebut Riffaterre sebagai hipogram. Hipogram aktual merupakan latar penciptaan teks baru. Teeuw (Pradopo, 1999:84) menyebutkan bahwa latar penciptaan karya sastra bisa meliputi masyarakat, peristiwa dalam sejarah, ataupun alam dan kehidupan.

\section{Hasil dan Pembahasan \\ Analisis Heuristik dan Analisis Hermeneutik Sajak-Sajak Irianto Ibrahim dalam Situs Kesedihan}

Pembahasan terlebih dahulu melalui pembacaan heuristik terhadap sajak-sajak Irianto Ibrahim sebagai bentuk pembacaan yang pertama, lalu dilanjutkan dengan pembacaan hermeneutik sebagai bentuk pembacaan yang kedua.

\section{Analisis Heuristik Sajak-Sajak Irianto Ibrahim dalam Situs Kesedihan}

Pembacaan ini berdasarkan struktur kebahasaannya. Guna memperjelas arti, pendeskripsiannya diberikan sisipan kata atau sinonim kata dalam tanda kurung bahkan diubah posisinya agar gramatikal. Hasil pembacaan tiap sajak tersebut sebagai berikut:

\section{Analisis Heuristik Sajak Pada Suatu Hari}

\section{Pada Suatu Hari}

ketika kau tanya padaku berapa jarak antara siang dan malam sesingkat senja, jawabku tidak lebih dari satu kedipan mata lalu kau tatap mataku seperti mencari sesuatu yang hilang mataku gelap dan dingin, katamu segelap malam, sedingin palung malam angin berhembus di antara kita bias senja menerpa wajahmu riak laut berwana keemasan dan di kejauhan sana tampak seorang nelayan yang memasang layar membiarkan angin membawanya pergi menjauh menuju pulau-pulau

kemudian kita beranjak pergi meninggalkan pantai dan bersiap menyalakan lampu-lampu berapa jarak antara malam dan siang, tanyamu lagi sesingkat fajar, jawabku tidak lebih dari satu kedipan mata lalu kau rebahkan kepalamu di dadaku menyimak detak jantungku sambil menghela nafas kemudian memejam mata angin berhembus perlahan di antara kita lolong anjing yang jauh bersahut-sahutan dua ekor cicak berebut laron yang mendekati cahaya dan samar-samar dari tetangga sebelah seorang ibu kedengaran memanggil anaknya

ketika tengah malam kau tiba-tiba terbangun

keringat memenuhi dahi dan lehermu 
wajahmu pucat

dan suaramu serak memanggilku

katakan padaku berapa jarak

antara hidup dan mati

sesingkat kedipan, jawabku

tidak lebih dari satu tarikan nafas

Kendari, Januari 2019

Berdasarkan kutipan tersebut, pembacaan heuristik sajak Pada Suatu Hari karya Irianto Ibrahim adalah sebagai berikut:

Secara umum sajak ini menggambarkan percakapan pada suatu hari antara dua orang tokoh, yang digambarkan penyair melalui si aku lirik dengan lawan bicaranya atau si kau lirik dalam sajak. Arti yang dideskripsikan secara heuristik pada bait pertama ialah pada suatu hari engkau (ber)tanya padaku berapa jarak (atau lama) antara (waktu) siang dan (waktu) malam, (jarak atau lama waktu siang dan waktu malam sangat singkat) sesingkat (waktu) senja (dimulai setelah matahari tenggelam saat cahaya masih terlihat di langit hingga datangnya waktu malam atau (isya) saat cahaya merah (atau syafak) benar-benar hilang) jawabku. (Jarak atau lamanya) tidak lebih dari satu kedipan mata (atau satu kali gerak kelopak mata).

Selanjutnya pada bait kedua, (setelah bertanya) lalu kau (men)atap (bola) mataku, seperti mencari sesuatu yang hilang. (Bola) mataku gelap (tanpa cahaya) dan dingin (seperti es), katamu. (Setelah menatap dan mencari sesuatu yang hilang, bola mataku) segelap malam (tanpa cahaya), sedingin palung (atau jurang yang berada di dasar laut) (tanpa cahaya seperti) malam (hari).

Pada bait ketiga, angin berhembus (dan terhempas) di antara kita (berdua), bias (cahaya) matahari senja menerpa (mengejar hendak menyergap) wajahmu, riak (ombak kecil) laut berwarna keemasan (akibat sinar matahari senja) dan di kejauhan sana (di tengah laut) tampak (atau terlihat) seorang nelayan yang memasang layar (perahu) membiarkan (tiupan) angin membawa (nelayan itu) pergi, menjauh (pergi berlayar) menuju pulau-pulau.

Pada bait keempat, kemudian (setelah perahu pergi dan cahaya senja telah menerpa wajahmu) kita beranjak pergi meninggalkan pantai. Dan (karena hari telah malam, kita) bersiap menyalakan lampu-lampu (sebagai penerangan). Berapa jarak (atau lama) antara (waktu) malam dan (waktu) siang, tanyamu lagi (padaku). (Sangat singkat) sesingkat (waktu) fajar (atau singkatnya saat cahaya kemerah-merahan di langit sebelah timur pada menjelang matahari terbit hilang berganti menjadi waktu pagi), jawabku. (Jarak atau lamanya) tidak lebih dari satu kedipan mata (atau satu kali gerak kelopak mata).

Pada bait kelima, lalu (eng)kau (me)rebahkan kepalamu di dadaku, menyimak (dan mendengarkan) detak jantungku sambil menghela nafas kemudian memejam(kan) mata(mu dan engkau tertidur).

Pada bait keenam, angin berhembus (dan terhempas) pelan di antara kita (berdua), (suara) lolong anjing yang (dari) ke(jauh)an bersahut-sahutan, (di dinding) dua ekor cicak berebut laron yang mendekati cahaya (lampu) dan (terdengar suara) samar-samar dari (rumah) tetangga sebelah seorang ibu kedengaran memanggil anaknya.

Pada bait terakhir, bait ketujuh ketika tengah malam (eng)kau tiba-tiba terbangun (dari tidurmu), keringat (bercucuran) memenuhi dahi dan lehermu, wajahmu pucat dan suaramu (terdengar) serak memanggilku. (Tanyamu kembali), katakan padaku berapa jarak antara hidup dan mati, (sangat singkat) sesingkat kedipan (atau gerak kelopak mata), jawabku tidak lebih dari satu tarikan nafas.

\section{Analisis Heuristik Sajak Percakapan Selepas Hujan}

Percakapan Selepas Hujan

ke mana perginya bintang-bintang di malam gelap begini rupa? 
Bersembunyi di antara gerimis

ataukah mengendap di balik bola matamu

kau menarik napas pelan

tak bisa bicara

tak ada jawaban

atau kau mengira

bintang-bintang telah berjatuhan

serupa daun gugur

di musim berangin begini?

hujan jadi deras

bunyi air di atap makin berisik

tidak sayangku. tidak begitu

pada kunang-kunang memang

kutemukan juga cahaya kerlip

tetapi bagi pelaut sepertiku

tak akan cukup hanya menghafal

suara ombak yang memukul lambung perahu

langit makin gelap laut juga gelap

hujan yang deras menghalau percakapan kita

kau mendekap tubuhmu dengan tangan gemetaran bibirku jadi biru menahan gigil

kemana perginya bintang-bintang di malam gelap begini rupa?

Kendari, Januari 2019

Berdasarkan kutipan tersebut, pembacaan heuristik sajak Percakapan Selepas Hujan karya Irianto Ibrahim adalah sebagai berikut:

Sajak kedua Irianto Ibrahim yang di muat dalam Situs Kesedihan yaitu percakapan yang berlangsung setelah turun hujan.

Pada bait pertama arti yang ditemukan ialah ke mana perginya bintang-bintang di malam gelap (biasanya bercahaya?), (dalam keadaan) begini rupa?, (gelap gulita) (bintang-bintang) bersembunyi di antara gerimis (malam hari). Atau (mungkin)kah mengendap (bersembunyi) di balik bola matamu(?).

Selanjutnya, pada bait kedua, (eng)kau menarik napas (lalu menghembuskannya dengan) pelan. (Engkau) tak bisa bicara, tak ada jawaban (sepatah katapun).

Pada bait ketiga, atau(kah) (eng)kau mengira bintang-bintang (di langit) telah berjatuhan?, Serupa daun gugur (di negara yang memiliki empat iklim?), di musim (pancaroba ditandai dengan) berangin begini (jika di daerah tropis)?, hujan (turun) (men)jadi (semakin) deras, bunyi air (hujan turun) di atap (se)makin berisik.

Pada bait keempat, tidak sayangku, tidak begitu. Pada kunang-kunang memang kutemukan juga cahaya (kerlap)kerlip, (akan) tetapi bagi (seorang) pelaut sepertiku, tak akan cukup hanya menghafal (atau mengingat) suara ombak yang (menabrak seperti) memukul lambung perahu.

Pada bait kelima, langit (se)makin gelap (tanpa cahaya), laut juga (semakin) (meng)gelap. (Suara rintik) hujan yang deras menghalau percakapan kita, kau mendekap tubuhmu (akibat dingin) dengan tangan gemetaran, bibirku (men)jadi (berwarna) biru menahan gigil (karena dinginnya malam diselimuti hujan).

Pada bait terakhir bait keenam, kemana perginya (cahaya) bintangbintang di malam gelap (tanpa cahaya) begini rupa?

Analisis Heuristik Sajak Yang Berakhir dengan Pertanyaan

Yang Berakhir dengan

\section{Pertanyaan}

bisakah kita saling bicara seperti dulu seperti ketika pertama bertemu dengan suara yang dipelankan dengan tatapan yang ditundukan saya merindukan degup jantungku yang dulu perasaan gembira seperti kanak-kanak: takjub pada segala hal baru atau ketawa terbahak-bahak yang sering kali berakhir tangisan, entah karena apa tapi usia tidak berhenti sampai di situ seumpama bola, ia menggelinding di tanah lapang disepak kaki-kaki takdir dan menjauh dari citacita seseorang akan memungutnya, mengembalikannya ke tanah lapang lagi. untuk disepak lagi hingga peluit menyudahi masih bisakah kita bicara seperti dulu saling memandang dengan tatapan teduh dan suara rendah serupa bisikan saya membayangkan suasana pagi yang syahdu menunggu matahari muncul dari balik gunung itu menghayati kesegaran daun-daun berembun dan menanti binar matamu tepat sesudah lampu teras itu dipadamkan adakah kau mengira segalanya hanya khayalan? hanya harapan kosong yang berakhir sia-sia? 
Kendari, Januari 2019

Berdasarkan kutipan tersebut, pembacaan heuristik sajak Yang Berakhir dengan Sebuah Pertanyaan karya Irianto Ibrahim, adalah sebagai berikut:

Sajak ketiga Irianto Ibrahim yang di muat dalam Situs Kesedihan digambarkan sebuah cerita yang berisi dengan pertanyaan yang merindukan masa-masa yang terjadi yang pernah dialami.

Pada bait pertama arti yang ditemukan ialah bisakah kita (berdua) saling bicara (dan berkomunikasi) seperti (waktu) dulu (kala?), Seperti ketika (waktu) pertama (kali) bertemu dengan (nada) suara yang dipelankan (dan) dengan tatapan yang ditundukan.

Selanjutnya pada bait kedua, saya merindukan (suara) degup jantungku yang dulu, perasaan gembira seperti kanakkanak: takjub (serta kagum) pada segala hal (yang) baru (ditemui) atau ketawa terbahak-bahak yang sering kali berakhir (dengan) tangisan, entah karena (hal) apa (akupun tidak mengerti).

Pada bait ketiga, tapi usia tidak berhenti sampai di situ, seumpama bola, ia menggelinding di tanah lapang (bergerak memutar berguling-guling di lapangan). Disepak kaki-kaki takdir (kaki pemain bola) dan (pergi) menjauh dari cita-cita. Seseorang (pemain lain) akan memungutnya, mengembalikannya ke tanah lapang lagi, untuk disepak lagi hingga peluit (wasit berbunyi) menyudahi (permainan).

Pada bait keempat, masih bisakah kita bicara (serta berkomunikasi) seperti (waktu) dulu (kala?), saling memandang dengan tatapan teduh (yang menenangkan hati) dan (nada) suara (di)rendah(kan) serupa bisikan. Saya membayangkan suasana pagi (hari) yang syahdu, menunggu (sinar) matahari muncul (dari arah timur) dari balik gunung itu, menghayati kesegaran daun-daun berembun dan menanti binar (bola) matamu tepat sesudah lampu teras itu dipadamkan.

Pada bait terakhir bait kelima, adakah (eng)kau mengira segalanya hanya khayalan?, hanya harapan kosong yang berakhir sia-sia?.

Pembacaan heuristik pada ketiga sajak Irianto Ibrahim tersebut tentunya belum memiliki makna secara konvensi sastra. Pembacaan tersebut hanya sebatas pemahaman arti bahasa atau sistem semiotik tingkat pertama.

\section{Analisis Hermeneutik Sajak-Sajak} Irianto Ibrahim dalam Situs Kesedihan

Sebagaimana telah ditegaskan pada pemahaman teori semiotik Riffaterre bahwa hasil yang didapat dari pembacaan level pertama atau heuristik, belum memadahi karena belum memberikan sebuah pemahaman yang memusat yang menggambarkan sebuah kesatuan struktur. Oleh karena itu, pembacaan kedua atau hermeneutik, menjadi penting untuk dapat menemukan kesatuan struktur makna puisi tersebut.

Selanjutnya peneliti melakukan wawancara dengan Irianto Ibrahim selaku pengarang sajak agar dapat menemukan latar belakang sejarah terciptanya puisi tersebut, memperkuat dan mendukung hasil analisis yang dilakukan. Wawancara dengan Irianto Ibrahim dilaksanakan pada 29 Januari 2020 pukul 11.22 Wita, bertempat di ruang Program Studi Pendidikan Seni, Pascasarjana, Universitas Halu Oleo.

\section{Analisis Hermeneutik Sajak Pada Suatu} Hari

Sajak Pada Suatu Hari secara umum menceritakan tentang perubahan yang begitu cepat dalam kehidupan. Berikut analisis hermeneutik sajak Pada Suatu Hari karya Irianto Ibrahim.

Pada suatu hari engkau bertanya padaku berapa jarak perubahan antara 
kesuksesan dan kegagalan, jarak perubahan kesuksesan dan kegagalan sangat dekat yaitu ketika usaha kita kurang dalam mengerjakan sesuatu maka kegagalan menghampiri.

Engkau tidak menemukan kebahagiaan dan keberhasilan dalam kehidupanku. Engkau bilang, aku mengalami kegagalan serta dalam keadaan tidak baik, berada dalam jurang kegagalan yang terdalam. Perubahan sehingga mengalami kegagalan begitu cepat terjadi dalam kehidupan.

Cobaan datang silih berganti dalam kehidupan, begitupun antara kesuksesan dan kegagalan ataupun apa saja dinamika dalam kehidupan ini yang sedang dihadapi biarlah terjadi. Sebab bukan hanya kita yang merasakannya, orang lainpun mengalaminya. Namun mereka-mereka yang berada di luar sana mencoba bangkit dari keterpurukan, menekuni profesinya dengan baik. Menerima apapun yang dirasakan dan tetap berusaha untuk bangkit dari setiap kegagalan atau hambatan yang dialami dengan melewati setiap rintangan yang menghadang.

Kemudian setelah kita menyaksikan usaha yang dilakukan orang lain bangkit dari keterpurukan, akhirnya kita juga memiliki semangat untuk bangkit. Harus berusaha melewati kegagalan dan rintangan dengan usaha-usaha agar tetap bisa melangsungkan kehidupan. Dalam melakukan usaha engkau kembali bertanya berapa jarak perubahan antara kegagalan sehingga mencapai kesuksesan. Untuk meraih sebuah kesuksesan atau bangkit dari kegagalan atau melewati sebuah rintangan kehidupan jaraknya yang mesti dihadapi itu sangat singkat, sesingkat pula ketika kita sukses menjadi gagal, sesingkat pula ketika kegembiraan sehingga menjadi sedih, sesingkat pula seperti dalam hubungan percintaan yang saling memuji, memuja, dan mencinta sehingga menjadi mencaci, mencela, dan membenci namun yang membedakan untuk dapat melewati rintangan itu ada usaha yang mesti dikerjakan serta semangat dan harapan dalam menjalani kehidupan, maka mustahil tidak melewati rintangan itu.

Kau setia menemani dan menjalani kehidupan bersamaku, ikut merasakan kelelahan dari kerasnya kehidupan yang kita jalani.

Cobaan kembali muncul menghampiri, pada saat ingin bangkit cobaan itu datang silih berganti, ditambah dengan banyaknya cibiran-cibiran di sekitar. Orang lain menginginkan kehidupan dari usaha yang dilakukan. Mereka mencoba untuk bertahan hidup serta ada persaingan untuk bangkit dari keterpurukan, rintangan, hambatan dan kegagalan. Namun dari suram dan kerasnya kehidupan, masih ada orang tua yang memberikan nasihat untuk tetap semangat menjalani dinamika kehidupan yang dijalani.

Beratnya kehidupan yang kita hadapai, engkau tetap setia menemani perjuanganku. Mencurahkan seluruh daya yang kamu miliki. Engkau begitu mempercayaiku dan kembali bertanya tentang kehidupan yang kita jalani tentang jarak antara hidup dan mati. Jaraknya sangat singkat, sesingkat kedipan atau gerak kelopak mata, tidak lebih dari satu tarikan nafas. Berakhirnya seluruh dinamika dalam kehidupan ini atau ending dari semua kehidupan antara kesuksesan dan kegagalan, antara kegembiraan dan kesedihan, antara percintaan yang kemudian saling membenci semuanya akan berakhir dengan jarak yang begitu singkat dan cepat.

\section{Analisis Hermeneutik Sajak Percakan Selepas Hujan}

Dalam sajak, penggambaran percakapan berlangsung sebelum turunnya hujan dan sedang berlangsungnya hujan, setelah turun hujan tidak ada percakapan antara kedua tokoh. Untuk itu, sajak percakapan selepas hujan 
dimaknai percakapan atau pembicaraan yang dilakukan setelah berusaha dan melewati kerasnya kehidupan.

Pemaknaan tersebut senada dengan apa yang diungkapkan pengarang bahwa, sajak Percakapan Selepas Hujan dalam penyusunannya, sebagaimana diketahui bahwa cuaca dan suasana kalau habis hujan itu bagus dan cerah. Tapi ini (dalam sajak) tidak secara implisit berbicara sesuatu selepas hujan, sebetulnya saya (Irianto Ibrahim) mencari kapan sebetulnya kita menyadari sesuatu yang ada, yaitu pada saat kita kehilangan, jadi kita menyadari sesuatu yang ada itu pada saat kita merasa kehilangan, pada saat dia sudah tidak ada baru kita mau cari (29/01/2020).

Percakapan atau pembicaraan setelah berusaha dan melewati kerasnya kehidupan. Sajak percakapan selepas hujan merupakan kelanjutan dari sajak pada suatu hari atau hipogram aktual sajak pada suatu hari.

Kemanakah kebahagiaan itu? Mengapa seperti engkau belum mendapatkannya sedangkan kita telah berusaha untuk menggapainya (sebagaimana usaha yang dilakukan pada sajak pada suatu hari). Apakah usaha yang dilakukan belum maksimal ataukah kebahagiaan itu sudah ada, hanya kita belum mensyukurinya. Dengan berbagai usaha yang kita kerjakan, kita seharusnya sudah bahagia dengan apa yang telah kita usahakan dan kita gapai. Namun, engkau belum menemukannya sehingga masih mengendap di balik bola matamu.

Entah membenarkan atau menolak. Namun, engkau diam. Tidak mampu berkata, hanya menarik napas.

Apakah kebahagiaan itu berlalu begitu saja dengan berbagai usaha yang kita lakukan dan banyaknya rintangan yang telah kita lalui.

Beratnya pembahasan tentang kebahagiaan ini.
Pada satu cara atau usaha memang ditemukan juga kebahagiaan. Namun, bagi seorang pekerja keras sepertiku tidak cukup dengan satu usaha dan satu rintangan saja.

Alotnya pembahasan kebahagian. Alhasil, kita belum merasakannya. Engkau belum merasakan kebahagiaan itu. Aku tahu, engkau lelah menemaniku. Namun engkau juga harus mengerti apa yang telah saya lakukan semua untuk kebahagiaanmu.

Kemanakah kebahagiaan yang seharusnya telah kita rasakan sebagai hasil kerja keras yang telah kita lalui?

\section{Analisis Hermeneutik Sajak Yang Berakhir dengan Pertanyaan}

Sajak Yang Berakhir dengan Pertanyaan karya Irianto Ibrahim mengambarkan kerinduan si aku lirik dalam sajak tentang masa-masa pertama kali menjalin hubungan dengan si kau lirik atau kekasihnya. Sajak Yang Berakhir dengan Pertanyaan juga merupakan kelanjutan dari Sajak Pada Suatu Hari dan sajak Percakapan Selepas Hujan karya Irianto Ibrahim.

$\begin{array}{rccc}\text { Sajak } & \text { Yang Berakhir dengan } \\ \text { Pertanyaan } & \text { karya Irianto Ibrahim }\end{array}$ mengambarkan kerinduan si aku lirik dalam sajak tentang masa-masa pertama kali menjalin hubungan dengan kekasihnya. Sajak Yang Berakhir dengan Pertanyaan juga merupakan kelanjutan dari Sajak Pada Suatu Hari dan sajak Percakapan Selepas Hujan karya Irianto Ibrahim.

Bisakah berbicara seperti pertama kali bertemu dulu dengan penuh kemesraan melalui kata-kata yang indah didengar dan dengan sikap yang menyejukan hati.

Saya merindukan perasaanku dulu. Merindukan semangat pada saat memulai suatu usaha yang pernah dirasakan, sehingga mendapati keadaan diri bahagia karena berhasil atau bersedih karena gagal dari semangat dan usaha baru yang 
digeluti. Saya tidak mengerti mengapa itu bisa terjadi.

Namun, kehidupan tidak berhenti pada satu masalah saja. Roda kehidupan terus berputar, kadang susah kadang bahagia. Dijalani oleh mereka-mereka yang sanggup menghadapinya meskipun tidak sesuai yang diharapkan. Akan ada orang lain yang memberikan arahan dan semangat untuk menggapai tujuan demi menjalani kehidupan yang bahagia, sampai batas waktu atau ajal yang ditetapkan sang pemilik kehidupan atau Allah SWT berakhir. Sebagaimana terdapat pada sajak Pada Suatu Hari bait keenam seorang ibu atau orang tua memberikan nasihat setelah menyaksikan kerasnya kehidupan yang dialami orang lain.

Apakah kejadian sebagaimana pertama kali bertemu dulu masih bisa terulang?. Berbicara seperti pertama kali bertemu, dengan penuh kemesraan melalui kata-kata yang indah didengar dan dengan sikap yang menyejukan hati.

Saya menghayalkan ketenangan dan kebahagiaan, hingga engkau turut pula merasakan kebahagiaan itu, serta memberikan sambutan dan apresiasi atas hasil kerja keras yang telah saya perjuangkan selama ini.

Apakah engkau mengira, yang saya khayalkan atas usaha dan kerja keras yang saya lakukan selama ini hanya sebatas mimpi? Hanya mimpi-mimpi yang berakhir dan berlalu begitu saja?

Terakhir Irianto Ibrahim menegaskan ketiga puisinya (sajak "Pada Suatu Hari" sajak "Percakapan Selepas Hujan" dan sajak "Yang Berakhir dengan Pertanyaan") yang di muat dalam buku Situs Kesedihan menyiratkan satu hal tentang kesadaran, terutama bagaimana mencari titik temu pada diri sendiri.

Pencarian Ketidaklangsungan Ekspresi Sajak-Sajak Irianto Ibrahim dalam Situs Kesedihan
Ketidaklangsungan ekspresi yang digunakan oleh penyair untuk menyampaikan makna, gagasan, atau pikiran dalam puisi disebabkan oleh tiga hal, yaitu pergantian arti (displacing of meaning), penyimpangan arti (distorting of meaning), dan penciptaan arti (creating of meaning).

Pencarian Ketidaklangsungan Ekspresi Sajak Pada Suatu Hari

Ketidaklangsungan ekspresi sajak Pada Suatu Hari karya Irianto Ibrahim disebabkan penggunaan penggantian arti, penyimpangan arti, dan penciptaan arti.

\section{Penggantian Arti pada Sajak Pada Suatu Hari}

Dalam sajak Pada Suatu Hari karya Irianto Ibrahim, penggantian arti menggunakan bahasa kiasan metafora dan kiasan simile.

a. kiasan metafora

Penggunaan kiasan metafora dalam sajak Pada Suatu Hari karya Irianto Ibrahim adalah sebagai berikut:

Pada bait pertama terdapat pada frasa "siang dan malam" mengganti "kesuksesan dan kegagalan", kata "senja" mengganti atau sebagai "jarak antara kesuksesan dan kegagalan", dan frasa "tidak lebih dari satu kedipan mata" mengganti "transformasi dari kecepatan perubahan yang terjadi".

Pada bait kedua terdapat pada kata "gelap dan dingin" mengganti arti "terpuruk dan gagal" dan frasa "segelap malam, sedingin palung malam" mengganti arti "berada dalam jurang kegagalan yang terdalam”.

Pada bait ketiga terdapat pada kata "angin" mengganti "cobaan", frasa "bias senja menerpa mengejar hendak menyergap wajahmu" mengganti arti "tentang apa yang sedang kita hadapi biarlah terjadi", frasa "riak laut berwarna keemasan" mengganti arti "bukan hanya kita yang merasakan, orang lainpun mengalaminya juga" pada baris $4,5,6$, dan 7 bait ketiga yaitu "dan di kejauhan 
sana tampak, seorang nelayan memasang layar, membiarkan angin membawanya pergi, menjauh menuju pulau-pulau" mengganti arti "namun mereka-mereka yang berada di luar sana mencoba bangkit dari keterpurukan, menekuni profesinya dengan baik. Menerima apapun yang dirasakan dan tetap berusaha untuk bangit dari setiap kegagalan yang dialami, melewati setiap rintangan yang menghadang".

Pada bait keempat terdapat pada frasa "bersiap menyalakan lampu-lampu" mengganti arti "kitapun harus berusaha melewati kegagalan dengan usaha-usaha", frasa "malam dan siang" mengganti "kegagalan dan kesuksesan", frasa "sesingkat fajar" mengganti "jarak perubahan" dan frasa "tidak lebih dari satu kedipan mata" mengganti "transformasi dari kecepatan perubahan yang terjadi".

Pada bait kelima terdapat pada frasa "kau rebahkan kepalamu di dadaku", frasa "menyimak detak jantungku" dan frasa "sambil menghela nafas" mengganti arti "setia menemani dan menjalani kehidupan bersamaku", "ikut merasakan kelelahan", "dari kerasnya kehidupan".

Pada bait keenam terdapat pada kata "angin" mengganti "cobaan", frasa "lolong anjing yang bersahut-sahutan" mengganti "banyaknya cibiran-cibiran orang di sekitar", frasa "dua ekor cicak berebut laron yang mendekati cahaya" mengganti arti "orang lain menginginkan kehidupan dari usaha yang kita kerjakan", frasa "samar-samar dari tetangga, sebelah seorang ibu memanggil anaknya" mengganti arti "dari suram dan kerasnya kehidupan yang dijalani, masih ada orang tua yang memberikan nasihat".

Pada bait ketujuh terdapat pada frasa "keringat memenuhi dahi dan lehermu" mengganti arti "beratnya kehidupan yang kita hadapi", frasa "jarak antara hidup dan mati" mengganti arti "kesuksesan menuju kegagalan dan kegagalan menuju kesuksesan" dan frasa "sesingkat kedipan" mengganti arti jarak perubahan", dan frasa "tidak lebih dari satu tarikan nafas" mengganti arti "transformasi dari kecepatan perubahan yang terjadi".

b. kiasan simile

Penggunaan kiasan simile dalam sajak Pada Suatu Hari karya Irianto Ibrahim yaitu terdapat pada bait kedua baris pertama dan kedua, lalu kau tatap mataku, seperti mencari sesuatu yang hilang, dihubungkan dengan bait sebelumnya baris tersebut memiliki makna "setelah bertanya tentang jarak perubahan kesuksesan dan kegagalan lalu kau menatap bola mataku, digambarkan seperti mencari sesuatu yang hilang" dalam baris pertama dan kedua bait kedua tersebut secara hakikat berbeda tetapi memiliki makna yang serupa, artinya jika ingin melihat keadaan seseorang, yang harus diperhatikan bagaimana keadaan keseharian seseorang tersebut mulai dari aktivitas dan lain sebagainya, namun yang ditampilkan dalam bait ini hanya dengan menatap bola mata yang mewakili secara keseluruhan keadaannya lalu disampaikan lebih lanjut mengenai keadaannya pada baris selanjutnya.

\section{Penyimpangan Arti pada Sajak Pada Suatu Hari}

Dalam sajak Pada Suatu Hari karya Irianto Ibrahim penyimpangan arti disebabkan oleh ambiguitas, yaitu penggunaan kata-kata, frase, kalimat, atau wacana yang taksa atau ambigu yang memiliki makna lebih dari satu tetapi dapat ditafsirkan bermacam-macam menurut konteksnya. Berikut uraiannya:

Dalam sajak Pada Suatu hari karya Irianto Ibrahim penyimpangan arti yang disebabkan oleh ambiguitas pertama terdapat pada bait pertama baris kedua dan ketiga yaitu jarak antara siang dan malam, sesingkat senja. Kutipan sajak tersebut bermakna ambigu yang dapat ditafsirkan lebih dari satu makna, seperti 
jarak antara kesuksesan sehingga menjadi gagal, jarak antara kegembiraan sehingga menjadi sedih, jarak antara hubungan percintaan yang sebelumnya saling memuji, memuja, dan mencinta sehingga menjadi mencaci, mencela, dan membenci kapan saja bisa berubah dengan cepat.

Kedua, terdapat pada bait keempat baris keempat dan kelima yaitu jarak antara malam dan siang, sesingkat fajar. Kutipan sajak tersebut bermakna ambigu yang dapat ditafsirkan lebih dari satu makna, seperti jarak antara kegagalan sehingga menjadi berasil dan sukses, jarak antara kesedihan yang dialami sehingga menjadi gembira, jarak antara hubungan percincaan yang sebelumnya saling mencaci, mencela, dan membenci sehingga memuji, memuja, dan mencinta kapan saja bisa berubah dengan cepat.

Ketiga, terdapat pada bait ketujuh baris ketujuh dan kedelapan yaitu jarak antara hidup dan mati, sesingkat kedipan. Kutipan sajak tersebut bermakna ambigu yang dapat ditafsirkan lebih dari satu makna, tentang jarak antara hidup dan mati, dimaknai sebagai pertanyaan tentang jarak berakhirnya seluruh dinamika dalam kehidupan ini atau ending dari semua kehidupan artinya antara kesuksesan dan kegagalan, antara kegembiraan dan kesedihan, antara percintaan yang kemudian saling membenci semuanya akan berakhir sebagaimana yang digambarkan dari keseluruhan sajak. Akhir dari kehidupan manusia bahwa ketika akan meninggal dunia meninggalkan semua apa yang ada di dunia, dengan proses yang begitu cepat.

\section{Penciptaan Arti pada Sajak Pada Suatu Hari}

Dalam sajak Pada Suatu Hari karya Irianto Ibrahim penciptaan arti disebabkan oleh enjambement yaitu perloncatan baris dalam sajak, membuat intensitas arti atau perhatian pada kata akhir atau kata yang diloncatkan ke baris berikutnya.
Pertama enjambement dalam sajak Pada Suatu Hari terdapat pada bait ketiga dan bait keenam dengan menempatkan bait ketiga dan keenam ini berbeda dengan bait pertama, bait kedua, bait keempat, bait kelima dan bait ketujuh dalam sajak. Penempatan yang berbeda ini bermakna sebagai penanda dimunculkannya konflik dalam sajak.

Dapat dilihat pada bait ketiga baris pertama "angin berhembus" dan terhempas "di antara kita" berdua, maksudnya, angin dapat dimaknai sebagai cobaan sebagaimana dalam kehidupan, cobaan pada manusia datang silih berganti. Hal yang sama terdapat pada bait keenam baris pertama "angin berhembus dan terhempas pelan di antara kita berdua", dimaknai cobaan kembali muncul menghampiri artinya cobaan itu memang datang silih berganti kapan saja bisa datang sehingga mengakibatkan perubahan.

Kedua enjamembent terdapat pada bait keempat dan bait ketujuh. Dikatakan bait keempat terdapat penciptaan arti melalui emjambemen karena terjadi perloncatan baris dalam sajak, membuat intensitas arti diloncatkan ke baris selanjutnya, yaitu pola penciptaan arti yang terdapat pada bait pertama yaitu "jarak antara siang dan malam" yang berarti menanyakan jarak perubahan antara kesuksesan sehingga menjadi gagal dan melompat pada bait keempat yaitu "jarak antara malam dan siang" berarti menanyakan jarak perubahan antara kegagalan sehingga mencapai kesuksesan dan bait ketujuh "jarak antara hidup dan mati" yang berarti jarak berakhirnya seleruh kehidupan, yang membedakan pada bait ketujuh menyampaikan sifat secara keseluruhan, penyebab perubahan kegagalan sehingga menjadi sukses dan perubahan kegagalan menuju kesuksesan.

Pencarian Ketidaklangsungan Ekspresi Sajak Percakapan Selepas Hujan 
Ketidaklangsungan ekspresi sajak Percakapan Selepas Hujan karya Irianto Ibrahim disebabkan penggunaan penggantian arti.

\section{Penggantian Arti pada Sajak Percakapan Selepas Hujan \\ Dalam sajak Percakapan Selepas} Hujan karya Irianto Ibrahim, penggantian arti menggunakan bahasa kiasan. Kiasan metafora adalah pemakaian kata atau kelompok kata bukan dengan arti yang sebenarnya, melainkan sebagai lukisan yang berdasarkan persamaan atau perbandingan.

a. kiasan metafora

Penggunaan kiasan metafora dalam sajak Percakapan Selepas Hujan karya Irianto Ibrahim adalah sebagai berikut:

Bait pertama, pada frasa "bintangbintang mengganti arti kebahagiaan", frasa "di antara gerimis mengganti arti usaha yang belum maksimal", frasa "mengendap di balik bola matamu mengganti arti kebahagiaan itu sudah ada, hanya belum mensyukurinya".

Bait kedua, pada frasa "menarik napas pelan mengganti arti entah membenarkan atau menolak yang diungkapkan".

Bait ketiga, pada baris kedua, ketiga dan keempat "bintang-bintang telah berjatuhan, serupa daun gugur, di musim berangin begini? mengganti arti, apakah kebahagiaan itu berlalu begitu saja dengan berbagai usaha yang kita lakukan dan banyaknya rintangan yang telah kita lalui".

Bait keempat, "hujan jadi deras, bunyi air di atap makin berisik mengganti arti beratnya pembahasan tentang kebahagiaan".

Bait kelima, pada frasa "cahaya kerlip kunang-kunang mengganti arti pada satu cara atau usaha memang ditemukan juga kebahagiaan", frasa "pelaut mengganti arti seorang pekerja keras", frasa "tidak akan cukup hanya menghafal suara ombak mengganti arti tidak cukup dengan satu usaha”.

Baait keenam, secara keseluruhan "langit makin gelap. laut juga gelap, hujan yang deras menghalau percakapan kita, kau mendekap tubuhmu dengan tangan gemetaran, bibirku jadi biru menahan gigil mengganti arti alotnya pembahasan kebahagian. Alhasil, kita belum merasakannya. Engkau belum merasakan kebahagiaan itu. Aku tau, engkau lelah menemaniku. Namun, engkau juga harus mengerti apa yang telah saya lakukan semua untuk kebahagiaanmu"

Bait ketujuh, pada kalimat "ke mana perginya bintang-bintang di malam gelap begini rupa? mengganti arti kemanakah kebahagiaan yang seharusnya telah kita rasakan sebagai hasil kerja keras yang telah kita lalui".

\section{Pencarian Ketidaklangsungan Ekspresi Sajak Yang Berakhir dengan Pertanyaan}

Ketidaklangsungan ekspresi sajak Yang Berakhir dengan Pertanyaan karya Irianto Ibrahim disebabkan penggunaan penggantian arti dan penciptaan arti.

\section{Penggantian Arti pada Sajak Yang Berakhir dengan Pertanyaan}

Dalam sajak Yang Berakhir dengan Pertanyaan karya Irianto Ibrahim, penggantian arti menggunakan bahasa kiasan metafora dan kiasan simile. Kiasan metafora adalah pemakaian kata atau kelompok kata bukan dengan arti yang sebenarnya, melainkan sebagai lukisan yang berdasarkan persamaan atau perbandingan. Kiasan simile adalah majas pertautan yang membandingkan dua hal yang secara hakiki berbeda, tetapi dianggap mengandung segi yang serupa, dinyatakan secara eksplisit dengan kata seperti, bagai, laksana.

a. kiasan metafora

Penggunaan kiasan metafora dalam sajak Yang Berakhir dengan Pertanyaan 
karya Irianto Ibrahim adalah sebagai berikut:

Pada bait pertama, frasa "suara yang dipelankan dan tatapan yang ditundukan mengganti kata-kata yang indah didengar dan dengan sikap yang menyejukan hati”.

Bait kedua secara keseluruhan, pada "Saya merindukan degup jantungku yang dulu, perasaan gembira seperti kanakkanak: takjub pada segala hal baru, atau ketawa terbahak-bahak yang sering kali, berakhir tangisan, entah karena apa mengganti saya merindukan perasaanku dulu. Merindukan semangat pada saat memulai suatu usaha yang pernah dirasakan, sehingga mendapati keadaan diri bahagia karena berhasil atau bersedih karena gagal dari semangat dan usaha baru yang digeluti. Saya tidak mengerti mengapa itu bisa terjadi”.

Bait ketiga, pada frasa "usia mengganti kehidupan", frasa "seumpama bola mengganti roda kehidupan", frasa "disepak kaki-kaki takdir mengganti dijalani oleh mereka-mereka yang sanggup", dan frasa "hingga peluit menyudahi mengganti sampai batas waktu atau ajal yang ditetapkan sang pemilik kehidupan atau Allah SWT berakhir".

Bait kelima, pada frasa "suasana pagi yang syahdu mengganti ketenangan dan kebahagiaan", frasa "menghayati kesegaran daun-daun berembun mengganti hingga engkau turut pula merasakan kebahagiaan itu", dan kalimat "menanti binar matamu tepat sesudah lampu teras itu dipadamkan mengganti memberikan sambutan dan apresiasi atas hasil kerja keras yang telah saya perjuangkan selama ini”.

Bait keenam, pada frasa segalanya mengganti usaha dan kerja keras yang dilakukan selama ini" dan frasa "hanya harapan kosong yang berakhir sia-sia? mengganti hanya mimpi-mimpi yang berakhir dan berlalu begitu saja?".

b. kiasan simile
Penggunaan kiasan simile dalam sajak Yang Berakhir dengan Pertanyaan karya Irianto Ibrahim terdapat pada kata usia yang dibandingkan dengan seumpama bola secara hakikat berbeda namun memiliki makna yang sama yaitu roda kehidupan.

\section{Penciptaan Arti pada Sajak Yang Berakhir dengan Pertanyaan}

Dalam sajak Yang Berakhir dngan Pertanyaan karya Irianto Ibrahim penciptaan arti disebabkan oleh enjambement yaitu perloncatan baris dalam sajak, membuat intensitas arti atau perhatian pada kata akhir atau kata yang diloncatkan ke baris berikutnya.

Enjambement pada sajak Yang Berakhir dengan Pertanyaan terdapat pada bait keempat, sebagaimana sama dengan yang disampaikan pada bait pertama yaitu menginginkan tatapan teduh dan suara rendah sebagaimana yang terdapat pada bait pertama. Apakah kejadian sebagaimana pertama kali bertemu dulu masih bisa terulang?. Berbicara seperti pertama kali bertemu, dengan penuh kemesraan melalui katakata yang indah didengar dan dengan sikap yang menyejukan hati. Terjadi perloncatan baris dalam sajak pada bait pertama membuat intensitas arti diloncatkan ke bait keempat sebagai penegasan kerinduan kehidupan seperti dulu yang diidamkan.

\section{Pencarian Matriks, Model, dan Varian Sajak-Sajak Irianto Ibrahim dalam Situs Kesedihan}

Secara teoretis sajak (karya sastra) merupakan perkembangan dari matriks menjadi model dan ditransformasikan menjadi varian-varian. Dalam analisis sajak (karya sastra), matriks diabstraksikan dari karya sastra yang dianalisis. Matriks ini dapat berupa satu kata gabungan kata, bagian kalimat atau kalimat sederhana. Untuk itu pencarian matriks, model dan varian akan dilakukan secara bersamaan pada setiap sajak-sajak 
Irianto Ibrahim yang di muat dalam Situs Kesedihan.

Pencarian Matriks, Model, dan Varian pada Sajak Pada Suatu Hari

Matriks dalam sajak Pada Suatu Hari adalah perubahan. Matriks ini dintransformasikan menjadi model atau dimodelkan dalam bentuk "kecepatan perubahan siang dan malam", "kedipan mata sebagai jarak dari siang dan malam" dan "senja sebagai antara dari jarak perubahan siang dan malam tersebut". Model tersebut merupakan kiasan atau metafora. Matriks tersebut ditransformasikan menjadi varian-varian berupa siang, malam, kedipan mata, dan senja. Karena siang, malam, kedipan mata, dan senja adalah perubahan waktu.

Pencarian Matriks, Model, dan Varian pada Sajak Percakapan Selepas Hujan

Matriks dalam sajak Percakapan Selepas Hujan adalah "tidak bersyukur". Matriks ini ditransformasikan menjadi model "Kemana perginya bintangbintang?, bersembunyi di antara gerimis atau mengendap di balik bola matamu? Model tersebut merupakan kiasan atau metafora. Matriks tersebut ditransformasikan menjadi varian-varian berupa "kemana perginya bintangbintang", "bersembunyi di antara gerimis", dan "mengendap di balik bola matamu". Karena "kemana perginya bintang-bintang", "bersembunyi di atara gerimis", dan "mengendap di balik bola matamu" adalah sebuah interpretasi dari rasa tidak bersyukur yang digambarkan dalam puisi.

\section{Pencarian Matriks, Model, dan Varian pada Sajak Yang Berkhir dengan Pertanyaan \\ Matriks dalam sajak Yang Berakhir} dengan Pertanyaan adalah "merindukan kehidupan yang bahagia". Matriks ini ditransformasikan menjadi model "bisakah saling bicara seperti dulu", "saya merindukan degup jantungku", "usia seumpama bola", "menanti binar matamu", dan "kau mengira hanya hayalan?" Model tersebut merupakan kiasan atau metafora. Matriks tersebut ditransformasikan menjadi varian-varian berupa "bisakah saling bicara seperti dulu", "saya merindukan degup jantungku", "usia seumpama bola", "menanti binar matamu", dan "kau mengira hanya hayalan?". Karena "bisakah saling bicara seperti dulu", "saya merindukan degup jantungku", "usia seumpama bola", "menanti binar matamu", dan "kau mengira hanya hayalan?" adalah interpretasi dari kerinduan akan kehidupan yang bahagia yang digambarkan dalam puisi.

\section{Pencarian Hipogram Sajak-Sajak} Irianto Ibrahim dalam Situs Kesedihan

Hipogram adalah hasil dari semiosis dan praktik kesasteraan serta tidak terdapat dalam teks. Oleh sebab itu, pencarian hipogram dalam sajak secara tidak langsung bersamaan dilaksanakan pada saat melakukan analisis secara hermeneutik. Tanda-tanda puisi dalam teks ditentukan oleh varian-varian atau beberapa transformasi dari sebuah matriks. Hipogram terbagi dua macam, yaitu hipogram potensial dan hipogram aktual. Hipogram potensial tidak tereksplisitkan dalam teks, tetapi diabstraksikan dari teks. Sedangkan hipogram aktual dapat berupa teks nyata, kata, kalimat, peribahasa, atau seluruh teks. Hipogram aktual ini menjadi latar penciptaan teks puisi.

\section{Hipogram Potensial Pada Sajak-Sajak Irianto Ibrahim dalam Situs Kesedihan}

Hipogram potensial ini adalah segala bentuk implikasi dari makna kebahasaan, baik yang berupa presuposisi, makna-makna konotatif yang sudah dianggap umum, dan sebagainya. Implikasi itu tidak akan dapat ditemukan di dalam kamus, misalnya, akan tetapi sebenarnya telah ada dalam pikiran penutur dalam bahasa pada umumnya. 
Pencarian hipogram potensial sajak-sajak Irianto Ibrahim dalam Situs Kesedihan telah bersamaan dilaksanakan dengan pencarian makna hermeneutik.

\section{Hipogram Aktual Sajak-Sajak Irianto Ibrahim dalam Situs Kesedihan}

Hipogram aktual merupakan latar penciptaan teks puisi. Hipogram berupa sebuah kalimat tunggal atau serangkaian kalimat yang terbuat dari klise, kutipan dari teks-teks lain, atau sebuah sistem yang deskriptif.

\section{Hipogram Aktual Sajak Pada Suatu Hari}

Untuk mengetahui hipogram aktual sajak Pada Suatu Hari karya Irianto Ibrahim, salah satu unsur yang menjadi perhatian yaitu sejarah kapan sajak tersebut ditulis. Dalam buku Situs Kesedihan disebutkan sajak Pada Suatu hari karya Irianto Ibrahim ditulis di Kendari pada bulan Januari tahun 2019, untuk tanggal tidak dideskripsikan kapan tepatnya sajak tersebut ditulis. Selain itu, metode wawancara juga dilakukan untuk menemukan informasi latar belakang atau sejarah puisi tersebut ditulis. Wawancara dilakukan pada tanggal 29 Januari 2020 pukul 11.22 Wita di ruang Program Studi Pendidikan Seni, Pascasarjana, Universitas Halu Oleo.

Matriks atau pusat makna sajak Pada Suatu hari yaitu perubahan. Matriks perubahan tersebut diperoleh dari interpretasi "jarak antara siang dan malam sesingkat senja dan tidak lebih dari satu kedipan" yang keseluruhannya merupakan perubahan waktu yang begitu cepat. Melalui wawancara, Irianto Ibrahim mengungkapkan dalam penulisan sajak Pada Suatu Hari yaitu gambaran tentang bagaimana ketika kita menyadari bahwa ternyata kita ini bukan siapa-siapa. Bagaimana kita kagum pada dunia, kita kagum pada keindahan yang sebetulnya semuanya sesaat, semuanya akan kembali, ini bukan punya kita, ini semua milik
Allah SWT. Mudah bagi Allah mengambil apa yang kita punya hari ini (29/01/2020).

Melalui wawancara tersebut Irianto Ibrahim kembali menegaskan apa yang mendasari dari lahirnya puisi Pada Suatu Hari. Bahwa sesungguhnya yang kita jalani, yang kita miliki, dan perubahan siklus kehidupan mudah bagi Allah SWT untuk mengaturnya.

Pernyataan tersebut bisa saja menyampaikan kepada kita semua tentang apa yang menjadi kegelisahan Irianto Ibrahim dalam benaknya sehingga dituangkan dalam puisi. Dari pernyataan tersebut diperoleh hipogram aktual dari sajak Pada Suatu Hari, dimana Irianto Ibrahim selaku pengarang dalam menciptakan sajak terinspirasi atau kagum menyaksikan kuasa Allah Swt. Firman Allah dalam al-Qur'an surah Yasin ayat 82: Innama Amruhu Idza Arada Syaian

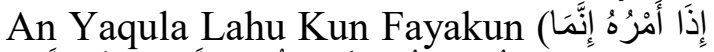
(فَيَكُونُ كُنْ لَهُ يَقُولَ أَنْ شَيْنًَا أَرَادَ Sesungguhnya urusannya-Nya apabila Dia menghendaki sesuatu hanyalah berkata kepadanya, Jadilah, Maka jadilah ia.

Pada ayat tersebut Allah Swt menerangkan betapa mudah bagi-Nya menciptakan sesuatu. Apabila Ia menghendaki untuk menciptakan sesuatu makhluk, cukuplah Allah berfirman: "Jadilah", maka dengan serta merta terwujudlah makhluk itu. Allah tidak akan pernah merasa susah untuk melakukan apapun, termasuk mengabulkan semua do'a yang dipanjatkan.

Allah maha kuasa untuk menciptakan segala sesuatu yang tidak terhitung jumlanya. Nasib hidup manusia, jodoh manusia, deburan ombak di lautan, rontoknya dedaunan, tetesan air hujan, tumbuhnya tunas-tunas, kelahiran bayi manusia, kelahiran anak hewan dari induknya, letusan gunung, sakitnya manusia dan kematiannya, serta berbagai peristiwa lainnya, semua itu adalah hal-hal 
yang telah dikehendaki Allah dan merupakan ciptaan-Nya.

Dengan demikian makna ayat dalam QS. Yasin: 82 adalah sebagai ungkapan bahwa Allah Swt maha kuasa untuk menciptakan segala sesuatu tanpa lelah, tanpa kesulitan, dan tanpa ada siapapun yang dapat menghalangi-Nya. Dengan kata lain, bahwa bagi Allah sangat mudah untuk menciptakan segala sesuatu yang Ia kehendaki, sesuatu tersebut dengan cepat akan terjadi, tanpa ada penundaan sedikitpun dari waktu yang Ia kehendakinya.

Sehingga dapat disimpulkan hipogram aktual atau latar penciptaan teks sajak Pada Suatu Hari karya Irianto Ibrahim adalah firman Allah Swt dalam al-Qur'an surah Yasin ayat 82 yaitu Innama Amruhu Idza Arada Syaian An Yaqula Lahu Kun Fayakun (أَرَادَ إِذَا أَمْرُهُ إِنَّمَا)

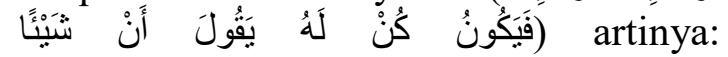
Sesungguhnya urusannya-Nya apabila Dia menghendaki sesuatu hanyalah berkata kepadanya, Jadilah, Maka jadilah ia.

\section{Hipogram Aktual Sajak Percakapan Selepas Hujan}

Pada analisis sebelumnya, telah diuraikan matriks atau pusat makna sajak Percakapan Selepas Hujan yaitu rasa 'tidak bersyukur". Matriks tersebut diperoleh dari transformasi model yang terdapat pada penggambaran "Kemana perginya bintang-bintang, begini rupa?, bersembunyi di antara gerimis atau mengendap di balik bola matamu?. Untuk selanjutnya akan ditemukan ruang kosong yang tidak ada secara tekstual yang menentukan terbentuknya sajak Percakapan Selepas Hujan sebagai puisi yang disebut sebagai hipogram aktual.

Sajak Percakapan Selepas Hujan merupakan sajak kedua Irianto Ibrahim yang di muat dalam buku Situs Kesedihan setelah sajak Pada Suatu Hari. Selain itu, kedua sajak tersebut juga ditulis pada waktu dan tempat yang sama yaitu bulan Januari tahun 2019.

Setelah ditinjau berdasarkan pusat makna atau matriks yang ada pada sajak Percakapan Selepas Hujan serta varianvarian yang ada pada sajak Pada Suatu Hari maka hipogram aktual sajak Percakapan Selepas Hujan adalah sajak Pada Suatu Hari.

Hal tersebut berdasarkan penggambaran bait keempat sajak Pada Suatu Hari yaitu:

Kemudian setelah kita menyaksikan usaha yang dilakukan orang lain bangkit dari keterpurukan, akhirnya kita juga memiliki semangat untuk bangkit. Kitapun harus berusaha melewati kegagalan dengan usahausaha, agar tetap bisa melangsungkan kehidupan. Dalam melakukan usaha engkau kembali bertanya berapa jarak antara kegagalan sehingga mencapai kesuksesan. Berapa jarak atau lama antara waktu malam dan waktu siang, baris ini dimaknai sebagai pertanyaan yang menanyakan perubahan jarak antara kegagalan yang dialami sehingga menjadi sukses. Si aku lirik menjawab jarak antara waktu malam dan waktu siang sangat singkat, sesingkat waktu fajar. Jawaban dari pertanyaan ini dapat dimaknai, bahwa untuk meraih sebuah kesuksesan atau bangkit dari kegagalan atau melewati sebuah rintangan kehidupan jarak yang mesti dihadapi itu sangat singkat, sesingkat pula ketika kita sukses menjadi gagal, sesingkat pula ketika kegembiraan sehingga menjadi sedih, sesingkat pula seperti dalam hubungan percintaan yang saling memuji, memuja, dan mencinta sehingga menjadi mencaci, mencela, dan membenci namun yang membedakan untuk dapat melewati rintangan itu ada usaha yang mesti dikerjakan serta semangat dan harapan dalam menjalani kehidupan, maka mustahil tidak 
melewati rintangan itu. Jawaban ini dipertegas dari baris-baris sebelumnya dan baris selanjutnya yang menyatakan jarak atau lamanya tidak lebih dari satu kedipan mata atau satu kali gerak kelopak mata.

Pada bait tersebut, dijelaskan untuk meraih sebuah kesuksesan yang bangkit dari kegagalan diperlukan usaha agar dapat mencapainya. Usaha yang dimaksud telah mereka lakukankan pada baris ketiga bait keempat sajak Pada Suatu Hari. Sedangkan pada sajak Percakapan Selepas Hujan makna berpusat pada rasa tidak bersyukur atas usaha yang dikerjakan, sehingga disimpulkan rasa tidak bersyukur yang ada pada sajak Percakapan Selepas Hujan merupakan rasa yang timbul atas apa yang telah diusahakan pada sajak Pada Suatu Hari.

Selain itu, disebut hipogram aktual sajak Percakapan Selepas Hujan adalah sajak Pada Suatu Hari juga diperkuat dengan penggambaran waktu yang ada pada sajak. Digambarkan pada sajak Pada Suatu Hari waktu yang digunakan yaitu, sore hari, ditandai dengan adanya bias senja dan malam hari ditandai dengan menyalakan lampu-lampu dan terbangun dari tidur. Penggambaran waktu tersebut dilanjutkan pada sajak Percakapan Selepas Hujan dimana digambarkan waktu malam hari ditandai dengan kemana perginya bintang-bintang di malam gelap begini rupa dan dengan langit yang makin menggelap sebagai penanda waktu malam hari.

\section{Hipogram Aktual Sajak Yang Berakhir dengan Pertanyaan}

Hipogram aktual sajak Yang Berakhir dengan Pertanyaan adalah sajak Pada Suatu Hari dan sajak Percakapan Selepas Hujan. Dikatakan demikian, sebab selain waktu dan tempat ditulisnya sajak-sajak ini bersamaan, makna dan pesan yang ingin disampaikan juga saling berhubungan dan saling melanjutkan.
Matriks atau pusat makna sajak Pada Suatu Hari ialah penyampaian nasihat tentang perubahan yang begitu cepat, melalui model jarak antara siang dan malam, tidak lebih dari satu kedipan, dan dengan varian-varian di antaranya yaitu jarak siang dan malam, jarak malam dan siang, dan menyalakan lampu-lampu sebagai bentuk usaha yang dikerjakan. Selanjutnya pada sajak Percakapan Selepas Hujan matriks atau pusat makna yang ditemukan ialah tentang kurang bersyukur dengan model yang ditampilkan ke mana perginya bintangbintang di malam gelap begini rupa? bersembunyi di antara gerimis atau mengendap di balik bola matamu?. Hal tersebut sejalan dengan matriks yang ada pada sajak Yang Berakhir dengan Pertanyaan. Matriks dalam sajak Yang Berakhir dengan Pertanyaan adalah "merindukan kehidupan yang bahagia" transformasi dari model "bisakah saling bicara seperti dulu, saya merindukan degup jantungku, usia seumpama bola, menanti binar matamu, dan kau mengira hanya hayalan?.

Kerinduan akan kehidupan yang bahagia yang terdapat pada sajak Yang Berakhir dengan Pertanyaan disinyalir berdasarkan kerinduannya pada perasaan yang dulu, yaitu dengan nada suara yang direndahkan. Sebagaimana perasaan tersebut tergambar pada sajak Pada Suatu Hari ketika kekasihnya bertanya padanya. Kerinduan akan kehidupan yang bahagia juga merupakan ungkapan perasaan dari tidak ditemukannya pada sajak Percakapan Selepas Hujan yang seharusnya mereka bisa berbahagia atas usaha yang dikerjakan, namun masih bersembunyi di antara gerimis atau masih mangendap di balik bola mata atau dengan kata lain, kekasihnya tidak bersyukur akan usaha yang dilakukan sehingga mereka belum berbahagia, sehingga kerinduan akan kebahagiaan tersebut dilukiskan 
pada sajak Yang Berakhir dengan Pertanyaan.

Selain berpusat pada makna, dikatakan hipogram aktual sajak Yang Berakhir dengan Pertanyaan adalah sajak Pada Suatu Hari dan sajak Percakapan Selepas Hujan, hipogram aktual tersebut juga dilihat dari segi waktu yang digambarkan di dalam sajak. Sajak Pada Suatu Hari digambarkan waktu sore hari, ditandai dengan adanya bias senja dan malam hari ditandai dengan menyalakan lampu-lampu dan terbangun dari tidur. Dilanjutkan pada sajak Percakapan Selepas Hujan dengan waktu yang digambarkan malam hari ditandai dengan kemana perginya bintang-bintang di malam gelap begini rupa dan dengan langit yang makin menggelap sebagai penanda waktu malam hari. Dan diakhiri pada sajak Yang Berakhir dengan Pertanyaan dengan penggambaran waktu pagi hari ditandai dengan menunggu matahari muncul dan lampu teras dipadamkan.

\section{Relevansi Penelitian Terhadap Pembelajaran Puisi di Sekolah}

Pembelajaran puisi pada mata pelajaran bahasa Indonesia, berdasarkan muatan kurikulum 2013 (K-13) edisi revisi 2017 di SMP Kelas VIII dan silabus satuan pendidikan, mata pelajara bahasa Indonesia kelas VII, memuat kompetensi dasar (3.7) mengidentifikasi unsur-unsur pembangun teks puisi yang diperdengarkan atau dibaca, (4.7) menyimpulkan unsur-unsur pembangun dan makna teks puisi yang diperdengarkan atau dibaca, (3.8) menelaah unsur-unsur pembangun teks puisi (perjuangan, lingkungan hidup, kondisi sosial, dan lainlain) yang diperdengarkan atau dibaca, dan (4.8) menyajikan gagasan, perasaan, pendapat dalam bentuk teks puisi secara tulis/lisan dengan memperhatikan unsurunsur pembangun puisi. Pada 3.8 kompetensi dasar, materi pokok dan materi pembelajarannya yaitu dengan menerangkan unsur lahir (bentuk) dan batin (makna) puisi, pengungkapan gagasan, perasaan, pandangan penulis dan pembacaan puisi (ekspresi, lafal, tekanan, intonasi). Dengan alokasi waktu pembelajaran bahasa Indonesia di SMP kelas VIII yaitu 6 jam/minggu.

Berdasarkan buku siswa Bahasa Indonesia kelas VIII dan silabus satuan pendidikan tersebut, maka penelitian ini sangat relevan dengan pembelajaran di sekolah dan penelitian ini layak untuk digunakan sebagai bahan ajar di sekolah. Dengan mempelajari unsur lahir atau bentuk puisi dan unsur batin atau makna puisi, pengungkapan gagasan, perasaan, pandangan penulis dan pembaca puisi yang terdapat dalam puisi maka siswa akan termotivasi untuk menambah dan menumbuh kembangkan kemampuan dalam memahami teks puisi.

Selain itu, karya sastra sangat mempengaruhi perkembangan intelektual peserta didik, dengan membaca peserta didik dapat mengaplikasikan nilai-nilai positif yang terdapat dalam kehidupan sehari-harinya.

\section{Kesimpulan}

Hasil penelitian ini menunjukan bahwa makna-makna yang terdapat dalam sajak Pada Suatu Hari, sajak Percakapan Selepas Hujan, dan sajak Yang Berakhir dengan Pertanyaan karya Irianto Ibrahim memiliki makna yang kompleks dan saling berhubungan satu sama lain.

\section{Daftar Pustaka}

Pradopo, Rachmat Djoko, 2011. PrinsipPrinsip Kritik Sastra. Yogyakarta: Gadjah Mada University Press.

Pradopo, Rachmad Jdoko. 1999. Semiotika: Teori, Metode, dan Penerapannya dalam Pemaknaan Sastra. Jurnal. Humaniora No.10.

Riffaterre, Michael, 1978. Semiotics of Poetry. London: Indiana University Press. 